\title{
Development of an online resource for recruitment research in clinical trials (ORRCA)
}

\author{
Nicola Harman ${ }^{1 *}$, Shaun Treweek ${ }^{2}$, Mike Clarke ${ }^{3}$, Paula Williamson ${ }^{1}$, Pete Bower ${ }^{1}$, Carrol Gamble ${ }^{1}$ \\ From 3rd International Clinical Trials Methodology Conference \\ Glasgow, UK. 16-17 November 2015
}

Recruitment to time and target remains a common challenge in the completion of a successful clinical trial. Since 2007 there has been significant investment in infrastructure to support clinical trials in the UK but the challenge of recruitment remains. The 2013 International Clinical Trials Methodology Conference demonstrated the volume of methodological research targeting recruitment. Furthermore, a 2014 survey of UK registered clinical trials units identified "research into methods to boost recruitment in trials" as the top priority for methodological research.

Research in this area needs to be managed in a resourceful way that will enable trialists and methodologists to access and use relevant research, to review methods that have been used to evaluate recruitment strategies and to identify areas that warrant further study. The ORRCA project aims to deliver this resource by creating a webenabled database populated with published and ongoing recruitment research. Eligible studies, identified from a search of the literature and contact with funders, will be categorised into key domains. We will include all eligible studies which report or assess recruitment strategies or interventions in the context of a clinical trial. This will include randomised comparisons and "case reports" of the specific recruitment strategy used in a clinical trial.

The key domains, developed for the web-enabled database, will be presented along with the search strategy and initial results mapped to the key domains. Areas requiring further research and prioritisation will be identified.

\footnotetext{
Authors' details

${ }^{1}$ North West Hub for Trials Methodology Research, Liverpool, UK. ${ }^{2}$ Health Services Research Unit, University of Aberdeen, Aberdeen, UK. ${ }^{3}$ All-Ireland Hub for Trials Methodology, Belfast, UK.
}

${ }^{1}$ North West Hub for Trials Methodology Research, Liverpool, UK Full list of author information is available at the end of the article
Published: 16 November 2015

doi:10.1186/1745-6215-16-S2-P98

Cite this article as: Harman et al:: Development of an online resource for recruitment research in clinical trials (ORRCA). Trials 2015 16(Suppl 2): P98.
Submit your next manuscript to BioMed Central and take full advantage of:

- Convenient online submission

- Thorough peer review

- No space constraints or color figure charges

- Immediate publication on acceptance

- Inclusion in PubMed, CAS, Scopus and Google Scholar

- Research which is freely available for redistribution

Submit your manuscript at www.biomedcentral.com/submit
() Biomed Central
C Biomed Central

(c) 2015 Harman et al. This is an Open Access article distributed under the terms of the Creative Commons Attribution License (http:// creativecommons.org/licenses/by/4.0), which permits unrestricted use, distribution, and reproduction in any medium, provided the original work is properly cited. The Creative Commons Public Domain Dedication waiver (http://creativecommons.org/publicdomain/ zero/1.0/) applies to the data made available in this article, unless otherwise stated. 